\title{
ALTERNATE FORMULA FOR CALCULATING THE DARCY COEFFICIENT IN TURBULENT FLOW IN PIPES
}

\author{
Freddy Lizardo Kaseng Solis \\ National University Federico Villarreal, (Perú). \\ E-mail: fkaseng@unfv.edu.pe ORCID: https:// orcid.org/0000-0002-2878-9053
}

Remo Bayona Antúnez

National University Federico Villarreal, (Perú).

E-mail: remobayona@yahoo.com ORCID: https:// orcid.org/0000-0001-8655-1193

Giro Rodriguez Rodriguez

National University Mayor de San Marcos, (Perú).

E-mail: crodriguezro@unmsm.edu.pe ORCID: https:// orcid.org/0000-0003-2112-1349

\section{Citación sugerida:}

Kaseng, F.L., Bayona, R., y Rodriguez, C. (2020). Alternate formula for calculating the Darcy Coefficient in turbulent flow in pipes. 3C Tecnologia. Glosas de innovación aplicadas a la pyme, 9(3), 99-109. https://doi.org/10.17993/3ctecno/2020. v9n3e35.99-109 


\section{ABSTRACT}

The purpose of this research was to determine an alternative formula for calculating the Darcy coefficient in turbulent flow in pipes. The proposed alternate formula is an explicit formula that should be used to replace the Colebrook-White formula for calculating the Darcy coefficient in turbulent flow in pipes since it has higher precision than the explicit formulas that are currently in use. In this investigation, the alternate formula was compared with two explicit formulas commonly used in pipe design, the Swamee-Jain and Pavlov formulas. To determining which formula is better, all of them were compared with the Colebrook-White formula. For this, the average percentage and maximum percentage errors of the Darcy coefficient values calculated with each of the explicit formulas were determined, with the values obtained with the Colebrook - White formula. It was determined that the maximum errors in the calculation of the Darcy coefficient concerning the Colebrook-White formula were: 3,104\% for the Swamee-Jain formula, 7,973\% for the Pavlov formula and 2,740\% for the alternate formula.

\section{KEYWORDS}

Pipes, Turbulent Flow, Darcy Coefficient, Colebrook-White Formula, Swamee-Jain Formula, Pavlov Formula, Alternate Formula. 


\section{INTRODUCTION}

An important part of the design of simple or complex hydraulic systems is the calculation of pressure pipes. As in all calculations, the designer seeks precision and simplicity, which are opposed, since generally, the simplicity carries with it the loss of accuracy. That loss of precision must be as little as possible for the simplification to make sense since a significant loss of precision would make the proposed simplification inappropriate.

A well-known formula for calculating the Darcy coefficient for turbulent flow in pipes is the ColebrookWhite formula. This formula has been used to prepare graphs for determining the Darcy coefficient, as is the case of the Moody diagram. However, the Colebrook-White formula has the drawback of being an implicit formula, which has to be solved by successive approximations, which is inconvenient for the calculation.

There are many explicit formulas to solve this problem that have been proposed that try to approximate the results obtained with the Colebrook-White formula. Anaya et al. (2014) indicate that Pavlov's formula is the most recommended to replace the Colebrook-White implicit formula. According to Mott (2006), the Swamee-Jain formula produces values for the Darcy coefficient, which are within $\pm 1.0 \%$ of the value of those corresponding to the Colebrook-White equation, within the range of relative roughness between 0.001 and 1x10-6 and for Reynolds numbers ranging from 5x103 to 1x108.

In the present research, it was demonstrated that an alternative formula, proposed by the author, has higher precision than the formulas that are mentioned and that are currently used, classification algorithms could be used as Huapaya et al. (2020), and Levy et al. (2020).

\section{MATERIAL AND METHODS}

The research design was quasi-experimental; because variables were manipulated to obtain Darcy coefficients by different formulas. 
According to Spiegel and Stephens (2009), the sample size as for an infinite or unknown population is:

$$
n=\frac{Z_{\alpha}^{2} p q}{i^{2}}
$$

Where:

$\mathrm{n}$ : sample size

Za: value corresponding to the Gaussian distribution

$\mathrm{p}$ : expected prevalence of the parameter to be evaluated, if unknown $(\mathrm{p}=0.5)$, which increases the sample size

$i$ : error

Sampling was carried out at the discretion of the researcher, proposing the values of Reynolds numbers and relative roughness indicated above. The samples were obtained by calculating through the respective formula (Colebrook - White, Swamee Jain, Pavlov, and alternate formula) the Darcy coefficients corresponding to predefined values of Reynolds numbers and relative roughness. The Reynolds number and relative roughness values used to obtain the sample were evenly distributed within the limits for which the Colebrook-White formula is valid, from 4000 to 108 for the Reynolds number and from 0.05 to 10-8 for the relative roughness.

The Darcy coefficient depends on the Reynolds number Re and the relative roughness $\varepsilon$ r.

Values of Reynolds numbers and relative roughnesses within the ranges of application of the ColebrookWhite formula were proposed, and the respective Darcy coefficients were determined with the ColebrookWhite, Swamee-Jain, Pavlov formulas and the alternate formula.

$$
\frac{1}{\sqrt{f}}=-2 \log \left(\frac{\varepsilon_{r}}{3.7}+\frac{2.51}{\operatorname{Re} \sqrt{f}}\right) \quad \text { Colebrook - White }
$$




$$
\begin{array}{ll}
f=\frac{0.25}{\left[\log \left(\frac{\varepsilon_{r}}{3.7}+\frac{5.74}{R e^{0.9}}\right)\right]^{2}} & \text { Swamee - Jain } \\
f=\frac{0.25}{\left[\log \left(\frac{\varepsilon_{r}}{3.7}+\frac{6.81}{R e^{0.9}}\right)\right]^{2}} & \text { Pavlov } \\
f=\frac{0.25}{\log \left(\frac{1}{3.7}\left\{\frac{\epsilon}{D}\right\}+\frac{6.81}{R e^{0.9}}\right)^{2}} \quad \text { Alternate formula }
\end{array}
$$

It was worked with a sample of 70007 Darcy coefficient values for each of the formulas used, comparing each of the explicit formulas (Swamee - Jain, Pavlov, and the alternate formula) with the implicit Colebrook - White formula.

For each of the explicit formulas, the mean percentage error em and the maximum percentage error Emax were obtained for the Colebrook White formula. Then these errors were compared with each other to determine which of the formulas is the most appropriate for the calculation of the Darcy coefficient in pipes with turbulent flow.

The calculations were carried out on an Excel spreadsheet, resulting in Table 1. 
Table 1. Calculation of the percentage errors of the explicit formulas to the Colebrook - White formula.

\begin{tabular}{|c|c|c|c|c|c|c|c|c|c|c|c|c|c|c|c|}
\hline \multirow[b]{2}{*}{$\mathbf{N}^{\circ}$} & \multirow[b]{2}{*}{$\operatorname{Re}$} & \multirow[b]{2}{*}{$\varepsilon_{r}$} & \multirow{2}{*}{$\begin{array}{c}\text { Colebrook } \\
\mathrm{f}\end{array}$} & \multicolumn{4}{|c|}{ Swamee - Jain } & \multicolumn{4}{|c|}{ Pavlov } & \multicolumn{4}{|c|}{ Alternate formula } \\
\hline & & & & $f_{1}$ & $e_{1}$ & $\left|e_{1}\right|$ & $e_{m}$ & $f_{2}$ & $e_{2}$ & $\left|e_{2}\right|$ & $e_{m}$ & $f_{3}$ & $e_{3}$ & $\left|e_{3}\right|$ & $e_{m}$ \\
\hline 1 & 4000 & 0,05 & 0,07699 & 0,0794 & 3,104 & 3,104 & 0,551 & 0,08079 & 4,936 & 4,936 & 1,683 & 0,07885 & 2,416 & 2,416 & 0,236 \\
\hline 2 & 4000 & $1,00 \mathrm{E}-03$ & 0,04091 & 0,0417 & 1,931 & 1,931 & $\mathbf{e}_{\max }$ & 0,04415 & 5,875 & 7,920 & $\mathbf{e}_{\max }$ & 0,04073 & $-0,440$ & 0,440 & $e_{\max }$ \\
\hline 3 & 4000 & $1,00 \mathrm{E}-04$ & 0,04001 & 0,0407 & 1,650 & 1,650 & 3,104 & 0,0432 & 6,221 & 7,973 & 7,973 & 0,03967 & $-0,850$ & 0,850 & 2,416 \\
\hline 4 & 4000 & $1,00 \mathrm{E}-05$ & 0,03992 & 0,0406 & 1,603 & 1,603 & & 0,0431 & 6,262 & 7,966 & & 0,03956 & $-0,902$ & 0,902 & \\
\hline 5 & 4000 & $1,00 \mathrm{E}-06$ & 0,03991 & 0,0406 & 1,604 & 1,604 & & 0,04309 & 6,264 & 7,968 & & 0,03955 & $-0,902$ & 0,902 & \\
\hline 6 & 4000 & $1,00 \mathrm{E}-07$ & 0,03991 & 0,0406 & 1,604 & 1,604 & & 0,04309 & 6,264 & 7,968 & & 0,03955 & $-0,902$ & 0,902 & \\
\hline 7 & 4000 & $1,00 \mathrm{E}-08$ & 0,03991 & 0,0406 & 1,604 & 1,604 & & 0,04309 & 6,264 & 7,968 & & 0,03955 & $-0,902$ & 0,902 & \\
\hline 8 & 10000 & 0,05 & 0,07178 & 0,072 & 0,306 & 0,306 & & 0,07208 & 0,111 & 0,418 & & 0,07197 & 0,265 & 0,265 & \\
\hline 9 & 10000 & $1,00 \mathrm{E}-03$ & 0,02217 & 0,0223 & 0,767 & 0,767 & & 0,02277 & 1,926 & 2,706 & & 0,02218 & 0,045 & 0,045 & \\
\hline 10 & 10000 & $1,00 \mathrm{E}-04$ & 0,01851 & 0,0185 & $-0,324$ & 0,324 & & 0,01913 & 3,686 & 3,350 & & 0,01818 & $-1,783$ & 1,783 & \\
\hline 11 & 10000 & $1,00 \mathrm{E}-05$ & 0,01804 & 0,0179 & $-0,665$ & 0,665 & & 0,01865 & 4,074 & 3,381 & & 0,01763 & $-2,273$ & 2,273 & \\
\hline 12 & 10000 & $1,00 \mathrm{E}-06$ & 0,018 & 0,0179 & $-0,722$ & 0,722 & & 0,0186 & 4,085 & 3,333 & & 0,01757 & $-2,389$ & 2,389 & \\
\hline 13 & 10000 & $1,00 \mathrm{E}-07$ & 0,01799 & 0,0179 & $-0,723$ & 0,723 & & 0,01859 & 4,087 & 3,335 & & 0,01757 & $-2,335$ & 2,335 & \\
\hline 14 & 10000 & $1,00 \mathrm{E}-08$ & 0,01799 & 0,0179 & $-0,723$ & 0,723 & & 0,01859 & 4,087 & 3,335 & & 0,01757 & $-2,335$ & 2,335 & \\
\hline 15 & 20000 & 0,05 & 0,07167 & 0,0718 & 0,167 & 0,167 & & 0,07183 & 0,056 & 0,223 & & 0,07177 & 0,140 & 0,140 & \\
\hline
\end{tabular}

Source: authors' own elaboration.

Table 1 shows the following percentage errors:

- $\quad$ el (percentage error of the Swamee - Jain formula to the Colebrook - White formula)

- $\quad$ 2 (percentage error of Pavlov's formula to Colebrook-White's formula)

- $\quad$ e3 (percentage error of the alternate formula to the Colebrook - White formula)

These errors are determined using the following formulas:

$$
\begin{aligned}
& e_{3}=\frac{f_{3}-f}{f} \cdot 100 \% \\
& e_{2}=\frac{f_{2}-f}{f} \cdot 100 \% \\
& e_{1}=\frac{f_{1}-f}{f} \cdot 100 \%
\end{aligned}
$$


Where:

$\mathrm{f}$ is the value of the Darcy coefficient calculated with the Colebrook - White formula.

$\mathrm{fl}$ is the value of the Darcy coefficient calculated with the Swamee - Jain formula.

$\mathrm{f} 2$ is the value of the Darcy coefficient calculated with the Pavlov formula.

$\mathrm{f} 3$ is the value of the Darcy coefficient calculated with the alternative formula.

\section{RESULTS}

The testing of the hypothesis was performed by comparing the mean and maximum percentage errors, obtained from the comparison between the Darcy coefficients calculated with each of the explicit formulas, and the Darcy coefficients obtained by the Colebrook-White formula.

- emed 1 and emax 1 the mean percentage and maximum percentage errors obtained when calculating the Darcy coefficients with the Swamee-Jain formula, compared to those obtained using the Colebrook-White formula.

- emed2 and emax2 the mean percentage and maximum percentage errors obtained when calculating Darcy coefficients with the Pavlov formula, compared to those obtained using the Colebrook White formula.

The summary of the errors is shown in Table 2:

Table 2. Percentage errors of explicit formulas.

\begin{tabular}{|c|c|c|c|}
\hline & Swamee - Jain & Pavlov & Alternate \\
\hline $\mathbf{e}_{\mathbf{m}}$ & 0,551 & 1,683 & 0,236 \\
\hline $\mathbf{e}_{\max }$ & 3,104 & 7,973 & 2,416 \\
\hline
\end{tabular}

Source: authors' own elaboration. 
As can be seen, for the sample used, the alternate formula presents a mean percentage error of $0.236 \%$ and a maximum percentage error of $2.416 \%$ on the Colebrook-White formula. Both values are significantly smaller than the errors in the Swamee - Jain, and Pavlov formulas.

\section{DISCUSSION}

The results do not agree with the results obtained by Anaya et al. (2014), who propose Pavlov's formula for calculating the Darcy coefficient. The use of a single relative roughness value of 0.001 in that investigation may have led to less than exact conclusions.

The statement of Mott (2006) is confirmed in that the Swamee-Jain formula is a good alternative for calculating the Darcy coefficient for turbulent flow in pipes.

The alternate formula outperforms the other formulas. It has an average error equal to $42.7 \%$ of the average error of the Swamee - Jain formula and equivalent to $14 \%$ of the error of the Pavlov formula. As for the maximum error, this is $77.8 \%$ of the maximum error of the Swamee-Jain formula and $30.3 \%$ of the maximum error of the Pavlov formula.

It is concluded that the alternative formula is the best option for calculating the Darcy coefficient for turbulent flow in pipes.

\section{CONCLUSION}

The alternate formula outperforms the other formulas. It has an average error equal to $42.7 \%$ of the average error of the Swamee - Jain formula and equivalent to $14 \%$ of the error of the Pavlov formula. As for the maximum error, this is $77.8 \%$ of the maximum error of the Swamee-Jain formula and $30.3 \%$ of the maximum error of the Pavlov formula. 
It is concluded that the alternative formula is the best option for calculating the Darcy coefficient for turbulent flow in pipes.

\section{REFERENCES}

Anaya, A. I., Gauich, G. I., Funabazama, O., \& Gracia, V. A. (2014). Evaluación de ecuaciones del factor de fricción explícito en tuberías. Educación Química, 128-134.

Camaraza, Y., \& García, O. F. (2008). Ecuación explícita para el cálculo de factores de fricción en la zona de transición del flujo turbulento. Universidad de Matanzas "Camilo Cienfuegos".

Escuela Universitaria de Ingeniería Técnica Agrícola de Giudad Real. (s.f.). Expresiones del factor de fricción. Ciudad Real. https://previa.uclm.es/area/ing_rural/Hidraulica/Temas/Tema7.pdf

Fernández, B. (1999). Introducción a la Mecánica de Fluidos. Alfaomega grupo editor SA.

Giles, R., Evett, J., \& Liu, C. (1980). Mecánica de los Fluidos e Hidráulica. Mc Graw Hill.

Guerrero, J. O. (1995). Ecuación modificada de Colebrook - White. Ingeniería Hidráulica en México, 43-48.

Huapaya, H. D., Rodriguez, G., \& Esenarro, D. (2020). Comparative analysis of supervised machine learning algorithms for heart disease detection. 3C Tecnología. Glosas De Innovación Aplicadas a La Pyme, 233-247. https://ojs.3ciencias.com/index.php/3c-tecnologia/article/view/1003

Levy, J., Pandey, B., Chowdhry, B., \& Rodriguez, C. (2020). Prologue: Recent trends in computer science and engineering (RTCSE). 3C Tecnología. Glosas De Innovación Aplicadas a La Pyme, 19-25. https://ojs.3ciencias.com/index.php/3c-tecnologia/article/view/991

Mott, R. (2006). Mecánica de Fluidos Aplicada. Prentice Hall Hispanoamericana SA.

Munson, B., Young, D., \& Okiishi, T. (1999). Fundamentos de Mecánica de Fluidos. Editorial Limusa SA. 
Perez, D., \& Echeverría, J. (2002). Evolución histórica de las fórmulas para expresar las pérdidas de carga en tuberías. Ingeniería Hidráulica y Ambiental.

Saldarriaga, J. (1998). Hidráulica de tuberías. Mc Graw Hill Interamericana SA.

Shames, I. (1995). Mecánica de Fluidos. Mc Graw Hill.

Soto, B., Vega, H., Guzmán, Y., Rodriguez, G., \& Quinto, D. (2020). Classification algorithm based on machine learning to optimize athletes talent detection. Test Engineering, 83, 13464-13471.

Universidad de Sevilla. (s.f.). Open Course Ware Universidad de Sevilla. http://ocwus.us.es/ingenieriaagroforestal/hidraulica-y-riegos/temario/Tema\%202.Conducciones\%20forzadas/tutorial_03. htm 
